\title{
Efektivitas Penggunaan Website pada Ibu Nifas sebagai Inovasi Baru Media Edukasi Gizi tentang Pemberian Makanan Bayi dan Anak di Ruang Rawat Inap Peristi RSUD Sidoarjo
}

The Effecitivity of Website using in Postpartum Mother as New Innovation of Media Education about Complementary Feeding for Infant ant Toddler at Peristi Room RSUD Kabupaten Sidoarjo

\author{
${ }^{\square}$ Pudji Astutik, Rosida Indriani, Rohmawati, Pipit Sulistyowati \\ Instalasi Gizi RSUD Sidoarjo, Indonesia
}

DOI: 10.32781/cakrawala.v15i1.357

\begin{tabular}{l}
\hline ARTICLE INFO \\
Website, \\
Ibu Nifas, \\
Media Edukasi Gizi, \\
Pemberian Makanan Ban \\
dan Anak. \\
\hline Article History: \\
Received : 2 Nov 2020 \\
Accepted : 17 Juni 2021 \\
Publish : 18 Juni 2021
\end{tabular}

Corresponding author :

Address : Jl. Mojopahit No. 667, Sidoarjo, Jawa Timur

Email : pudjiastutik51@yahoo.com \begin{abstract}
Abstrak:
Untuk mengetahui efektivitas penggunaan media website pada ibu nifas sebagai inovasi baru media edukasi gizi tentang pemberian makanan bayi dan anak di Ruang Rawat Inap Peristi RSUD Kabupaten Sidoarjo. Penelitian ini menggununakan studi kuasi eksperimental, pre-test dan post test intervention. Teknik pengambilan sampel pada penelitian ini menggunakan total sampling yang berarti jumlah sampel sama dengan jumlah populasi yaitu 32 orang pada masing-masing kelompok. Hasil penelitian menunjukkan bahwa terdapat perbedaan yang signifikan antara tingkat pengetahuan ibu nifas sebelum dan sesudah diberikan edukasi mengenai Pemberian Makan Bayi dan Anak baik melalui leaflet $(p=0,050)$ website $(P=0,001)$. Hasil uji beda skor pengetahuan ibu antara kelompok leaflet dan website menunjukkan bahwa tidak terdapat perbedaan yang signifikan $(P=0,367)$. Website dapat digunakan sebagai alternatif media edukasi mengenai Pemberian Makan Bayi dan Anak pada ibu nifas.

Abstract:

To investigate the effecitivity of website using in postpartum mother as new innovation of media education about complementary feeding for infant ant toddler at Peristi room RSUD Kabupaten Sidoarjo. This method of the study was quasi experimental, pre and post test intervention. The sampling technique was total sampling that entire population was included in this study and divided into two groups. Each group had 32 respondents. The study showed that the level of knowledge before and after nutrition education using leaflet $(P=0.050)$ and website $(P=0.001)$ were significantly different. There was no significant different between the level of knowledge between leaflet groups and website groups $(P=0.367)$. Website could be used as an alternative education media about complementary feeding for infant and toddler in postpartum mother.
\end{abstract}




\section{PENDAHULUAN}

Gizi memiliki peranan penting bagi pertumbuhan dan perkembangan anak. Strategi Nasional Peningkatan Pemberian ASI dan MP-ASI merekomendasikan pemberian makanan yang baik dan tepat bagi bayi dan anak 0-24 bulan yaitu, inisiasi menyusu dini dalam 1 jam setelah lahir, pemberian ASI Eksklusif hingga usia 6 bulan, memberikan Makanan Pendamping ASI (MP-ASI) mulai 6 bulan, dan meneruskan pemberian ASI sampai usia 2 tahun. World Health Organization mendefinisikan ASI Eksklusif adalah pemberian ASI saja kepada bayi dari lahir hingga berusia 6 bulan tanpa memberikan makanan dan minuman lain, kecuali obat dan vitamin. MP-ASI adalah makanan atau minuman yang mengandung zat gizi untuk diberikan pada bayi atau anak usia 6-24 bulan dengan tujuan adagar dapat memenuhi kebutuhan gizi selain ASI (Departemen Kesehatan RI, 2006).

Berdasarkan hasil Riset Kesehatan Dasar (Riskesdas) tahun 2018, cakupan ASI Eksklusif di Indonesia mencapai 37,3 $\%$, angka ini lebih rendah dibandingkan dengan target WHO 2025 yaitu seluruh Negara memiliki cakupan ASI Eksklusif sebesar $50 \%$ dan target nasional cakupan pemberian ASI Eksklusif sebesar $80 \%$. Berdasarkan laporan bulanan Puskesmas, cakupan bayi yang mendapat ASI Eksklusif di Kabupaten Sidoarjo tahun 2018 sebesar $61,82 \%$ dari 4.518 bayi yang diperiksa. Berdasarkan hasil tersebut dapat diketahui bahwa cakupan pemberian ASI Ekslusif di wilayah Sidoarjo belum memenuhi target nasional (Profil Kesehatan Kabupaten Sidoarjo, 2018).

Di Indonesia pemberian MP-ASI dini sebelum anak berusia 6 bulan masih tergolong cukup tinggi. Terdapat 91,4\% bayi di Puskesmas Barusjahe Sumatera Utara telah mendapatkan MP-ASI usia kurang dari 6 bulan (Ginting dkk., 2013). Di wilayah Kota atau Kabupaten Malang pemberian MP-ASI dini pada tahun 2012- 2016 secara berturut-turut adalah sebesar $65 \%, 80 \%, 70 \%, 72 \%$, dan $46 \%$ persentase ini menunjukkan angka yang cukup besar dalam pemberian MP-ASI dini (Rahmawati et al., 2016). Pemberian MP-ASI dini dapat meningkatkan risiko terjadinya penyakit infeksi anak seperti diare, infeksi saluran napas, alergi, serta dapat mengganggu proses pertumbuhan anak (Fitriana et al., 2013). Pemberian MPASI dini dapat dipicu karena kurangnya pengetahuan ibu terhadap waktu yang tepat untuk memberikan MP-ASI serta motivasi diri dan keluarga yang kurang mendukung dalam pemberian ASI eksklusif pada bayinya (Ginting dkk., 2012). Salah satu upaya yang dapat dilakukan untuk mendukung penerapan ASI Eksklusif dan MP-ASI yang sesuai adalah melalui edukasi gizi terkait Pemberian Makanan Bayi dan Anak (PMBA).

Edukasi gizi adalah salah satu cara yang dapat dilakukan untuk meningkatkan pengetahuan tentang gizi dan perilaku makan sehingga mencapai status gizi optimal (Perdana dkk., 2017). Pelaksanaan edukasi dapat dilakukan dengan berbagai macam media seperti booklet, leaflet, video iklan layanan masyarakat, dan lain sebagainya. Perkembangan teknologi seperti internet dapat dimanfaatkan sebagai sarana dalam melakukan edukasi seperti penggunaan website. Keunggulan penggunaan media website diantaranya adalah mudah diakses oleh masyarakat luas dimana saja dan kapan saja. Selain itu, website dapat menyajikan data melaui tulisan, gambar, video maupun suara. Terdapat efektivitas bahan ajar berbasis web terhadap hasil belajar mahasiswa pada mata kuliah evaluasi proses dan hasil pembelajaran Universitas Baturaja (Yunarti dan Ningsih, 2019). Penelitian yang dilakukan Rohmawati (2018), di Kota Malang menunjukkan bahwa media website efektif dalam meningkatkan pengetahuan 
ibu hamil mengenai pemberian MP-ASI.

Berdasarkan masalah yang telah dipaparkan, peneliti berinovasi untuk melakukan penelitian mengenai efektivitas penggunaan website pada ibu nifas sebagai inovasi baru media edukasi gizi tentang pemberian makanan bayi dan anak di Ruang Rawat Inap Peristi RSUD Kabupaten Sidoarjo. Pelaksanaan penelitian ini adalah memberikan edukasi pada dua kelompok yaitu melalui media leaflet dan website. Hipotesis penelitian ini adalah website efektif sebagai inovasi media edukasi gizi.

\section{METODE PENELITIAN}

Penelitian ini menggunakan studi kuasi eksperimental, pre-test dan post-test intervention yang digunakan untuk melihat efektivitas penggunaan website pada ibu nifas sebagai inovasi baru media edukasi gizi tentang Pemberian Makanan Bayi dan Anak (PMBA) di Ruang Rawat Inap Peristi RSUD Kabupaten Sidoarjo. Studi kuasi eksperimental bertujuan untuk mengevaluasi intervensi yang telah diberikan dan dapat menunjukkan sebab akibat antara intervensi dan hasil. Hasil penelitian terkait penilaian efektivitas media website dibandingkan dengan efektivitas media leaflet untuk mengetahui seberapa besar perbedaan efektivitas dari kedua media. Rancangan penelitian ini adalah melakukan pre- test, kemudian memberikan perlakuan atau intervensi, dan melakukan post-tes (Notoatmodjo, 2012).

\section{$\mathrm{O} 1 \mathrm{a}-\mathrm{Xa}-\mathrm{O} 2 \mathrm{a}$ \\ $\mathrm{O} 1 \mathrm{~b}-\mathrm{Xb}-\mathrm{O} 2 \mathrm{~b}$ \\ Gambar 1 Skema Rancangan Penelitian}

Keterangan:

O1a: Pengetahuan ibu nifas sebelum mendapat edukasi gizi pada media leaflet $\mathrm{O} 1 \mathrm{~b}$ : Pengetahuan ibu nifas sebelum mendapat edukasi gizi pada media website O2a: Pengetahuan ibu nifas setelah mendapat edukasi gizi pada media leaflet

O2b: Pengetahuan ibu nifas setelah mendapat edukasi gizi pada media website

Xa : Intervensi edukasi gizi pada media leaflet

$\mathrm{Xb}$ : Intervensi edukasi gizi pada media website.

Populasi penelitian ini adalah semua ibu nifas di Ruang Rawat Inap Peristi Ibu RSUD Kabupaten Sidoarjo. Teknik pengambilan sampel pada penelitian ini menggunakan total sampling yang berarti jumlah sampel sama dengan jumlah populasi (Sugiyono, 2014). Jumlah sampel pada penelitian ini adalah 64 orang yang terbagi menjadi 2 kelompok yang masingmasing berjumlah 32 orang. Kriteria inklusi penelitian ini adalah ibu nifas yang berusia 17-45 tahun dan mampu berkomunikasi dengan baik, sedangkan untuk kelompok website ibu nifas sudah pernah mengakses internet website dan memiliki handphone atau smartphone.

Variabel bebas penelitian ini adalah edukasi gizi melalui media leaflet dan edukasi gizi melalui media website. Definisi Operasional Variabel (DOV) edukasi gizi melalui media leaflet yaitu suatu intervensi yang diberikan dengan tujuan untuk mengetahui adanya perubahan skor pengetahuan dengan cara pemberian edukasi gizi melalui media leaflet. DOV Edukasi gizi melalui media website adalah suatu intervensi yang diberikan dengan tujuan untuk mengetahui adanya perubahan skor pengetahuan dengan cara pemberian edukasi gizi melalui media website. Variabel terikat dalam penelitian ini adalah skor pengetahuan ibu nifas, perubahan skor pengetahuan ibu nifas pada masing-masing media, dan perbedaan skor pengetahuan ibu nifas antara media leaflet dan website. DOV skor pengetahuan ibu nifas dalam 
penelitian ini adalah skor kemampuan responden dalam menjawab dengan benar pertanyaan yang telah diberikan berkaitan dengan PMBA. Nilai maksimal pada penelitian ini adalah 100. Kategori skor pengetahuan dibagi menjadi 3 yaitu baik ( $>80 \%$ menjawab soal dengan benar), cukup (60-80\% menjawab soal dengan benar), dan kurang ( $<60 \%$ menjawab soal dengan benar). Perubahan skor pengetahuan ibu nifas antara media leaflet dan website adalah selisih skor pre-test dan post-test pengetahuan ibu nifas tentang PMBA melalui media leaflet dan website. Perbedaan skor pengetahuan ibu nifas antara media leaflet dan website adalah perbedaan selisih skor pengetahuan ibu nifas tentang PMBA antara media leaflet dan media website.

Pengambilan data penelitian ini meliputi proses skrining untuk mendapatkan responden yang memenuhi kriteria inklusi. Selanjutnya membagi responden ke dalam dua kelompok edukasi gizi melalui media leaflet dan media website. Responden yang telah terpilih kemudian melakukan pre-test untuk menilai skor pengetahuan responden sebelum diberi edukasi gizi dengan kuesioner pre-test. Setelah itu masing-masing kelompok akan diberikan intervensi berupa edukasi gizi dengan media leaflet atau website. Selang 2 jam setelah dilakukan intervensi, responden melakukan post-test untuk mengetahui nilai skor pengetahuan responden terkait materi yang telah disampaikan. Pemberian waktu selang 2 jam digunakan untuk memberi kesempatan pada responden membaca ulang dan memahami sendiri materi yang telah diberikan melalui media leaflet atau website.

Analisis data diawali dengan melakukan uji normalitas menggunakan Kolmogorov-Smirnov Test. Untuk melihat perbedaan leaflet dan website terhadap usia ibu dan kelahiran pada data kategorikal menggunakan uji Chi- Square. Uji perbedaan skor pengetahuan sebelum dan sesudah edukasi gizi pada media leaflet dan website menggunakan uji statistik Paired T-Test karena data terdistribusi normal dan untuk mengetahui perbedaan pada kedua kelompok menggunakan uji statistik Independent Sample T-Test karena data terdistribusi normal.

\section{HASIL DAN PEMBAHASAN Karakteristik Responden}

Responden penelitian ini adalah ibu nifas yang berada di Ruang Rawat Inap Peristi Ibu RSUD Kabupaten Sidoarjo. Penelitian ini dilakukan selama satu minggu pada tanggal 28 Februari sampai 5 Maret 2020. Distribusi responden penelitian ini dapat dilihat pada tabel 1 .

Tabel 1. Karakteristik Responden

\begin{tabular}{|c|c|c|c|}
\hline Karakteristik & Leaflet $n=32$ & Website $n=32$ & Nilai p \\
\hline Usia & & & 0,001 \\
\hline 17-30 tahun & $19(59,4 \%)$ & $30(93,8 \%)$ & \\
\hline $31-45$ tahun & $13(40,6 \%)$ & $2(6,2 \%)$ & \\
\hline Kelahiran Ke & & & 0,230 \\
\hline$\leq 2$ & $27(47,4 \%)$ & $30(52,6 \%)$ & \\
\hline$>2$ & $5(71,4 \%)$ & $2(28,6 \%)$ & \\
\hline \multicolumn{4}{|l|}{ Akses Internet } \\
\hline$\geq 3 x /$ hari & - & $20(62,5 \%)$ & \\
\hline$<3 \mathrm{x} /$ hari & - & $12(37,5)$ & \\
\hline
\end{tabular}

Sumber: Data Diolah, 2020 
Jumlah sampel pada penelitian ini sebanyak 32 orang pada masing-masing kelompok dengan total sampel 64 orang. Responden penelitian berada pada rentang usia 17-45 tahun. Penelitian ini diawali dengan melakukan skrining pada sampel untuk menentukan masuk ke dalam kelompok leaflet atau website. Setelah dilakukan skrining, responden diberikan pre-test, kemudian intervensi dan selang 2 jam diberikan post-test.

Distribusi responden berdasarkan usia didapatkan hasil mayoritas kelompok leaflet berada pada usia 17-30 tahun sebanyak 19 orang $(59,4 \%)$ dan responden lainnya berada pada usia 31-45 tahun sebanyak 13 orang $(40,6 \%)$.

Hasil ini juga sama dengan kelompok website yang mayoritas responden berada pada usia 17-30 tahun sebanyak 30 orang $(93,8 \%)$ dan 2 orang lainnya $(6,2 \%)$ berada pada usia 31-45 tahun. Berdasarkan data karakteristik pada tabel 1 menunjukkan bahwa ada perbedaan usia antara usia ibu yang menggunakan leaflet dan website berdasarkan Uji Chi-Square dengan $\mathrm{p}=0,001$. Distribusi responden menurut kelahiran keberapa menunjukkan bahwa pada kelompok leaflet mayoritas berada pada kelahiran $\leq 2$ sebanyak 27 orang $(47,4 \%)$ dan kelahiran $>2$ sebanyak 5 orang $(71,4 \%)$. Pada kelompok website, distribusi responden menurut kelahiran keberapa menunjukkan bahwa mayoritas berada pada kelahiran $\leq 2$ sebanyak 30 orang $(52,6 \%)$ dan kelahiran $>2$ sebanyak 2 orang $(28,6 \%)$. Berdasarkan Uji ChiSquare kelahiran keberapa menunjukkan bahwa tidak ada perbedaan kelompok leaflet dan website dengan nilai $\mathrm{p}=0,230$. Pada kelompok website, responden yang mengakses internet $\geq 3 \mathrm{x} /$ hari sebanyak 20 orang $(62,5 \%)$, sedangkan yang mengakses internet $<3 \mathrm{x} /$ hari sebanyak 17 orang $(37,5$ $\%$ ). Seluruh responden setiap harinya paling sedikit mengakses internet sebanyak sekali. Pada penelitian ini, mayoritas responden kelompok website mengakses internet $\geq 3 \mathrm{x} /$ hari.

Menurut tabel 2, menunjukkan bahwa hasil pre-test kelompok perlakuan leaflet tidak ada yang memiliki skor dengan kategori baik sedangkan untuk kategori cukup sebanyak 3 orang $(9,4 \%)$ dan kategori kurang sebanyak 29 orang (90,6 \%). Berdasarkan hasil post-test kelompok leaflet terdapat peningkatan skor pengetahuan ibu yaitu sebanyak 1 orang $(3,1 \%)$ dengan kategori baik, 25 orang $(75,8 \%)$ kategori cukup, dan 6 orang $(18,8$ $\%)$ kategori kurang. Kategori pengetahuan ibu saat pre-test pada kelompok website dengan kategori baik sebanyak 3 orang $(9,4$ $\%)$, kategori cukup sebanyak 6 orang $(18,8$ $\%$ ), dan kategori kurang sebanyak 23 orang (71,9\%). Hasil ini meningkat setelah post-

Tabel 2. Kategori Pengetahuan Ibu

\begin{tabular}{lcc}
\hline Kategori Pengetahuan Ibu & \multicolumn{2}{c}{ Kelompok } \\
\cline { 2 - 3 } & Leaflet & Website \\
\hline Pre-test & $0(0 \%)$ & $3(9,4 \%)$ \\
\hline Baik & $3(9,4 \%)$ & $6(18,8 \%)$ \\
\hline Cukup & $29(90,6 \%)$ & $23(71,9 \%)$ \\
\hline Kurang & & $23(71,9 \%)$ \\
\hline Post-Test & $1(3,1 \%)$ & $7(21,9 \%)$ \\
\hline Baik & $25(78,1 \%)$ & $2(6,2 \%)$ \\
\hline Cukup & $6(18,8 \%)$ &
\end{tabular}

Sumber: Data Diolah, 2020 
test menjadi 23 orang $(71,9 \%)$ kategori baik, 7 orang $(21,9 \%)$ kategori cukup, dan 2 orang $(6,25 \%)$ kategori kurang.

Berdasarkan uraian di atas dapat diketahui bahwa pada kedua kelompok terdapat peningkatan pengetahuan setelah diberikan edukasi gizi. Peningkatan pengetahuan ini dapat dilihat dari meningkatnya jumlah responden yang masuk kedalam kategori cukup dan baik. Hasil penelitian ini sejalan dengan penelitian yang dilakukan oleh Sinuhaji (2018), menyatakan bahwa terdapat perbedaan yang signifikan antara tingkat pengetahuan ibu balita sebelum dan sesudah mendapatkan edukasi melalui media leaflet dengan p-value 0,000. Hasil penelitian ini juga sejalan dengan penelitian yang dilakukan oleh Arfan et al. (2010), yang menyatakan bahwa terdapat peningkatan rata-rata nilai post-test setelah dilakukan edukasi melalui $e$-file multimedia tentang kesehatan reproduksi remaja. Penelitian yang dilakukan oleh Ramadhani (2012), juga menyatakan bahwa terdapat peningkatan nilai pengetahuan pre-test ke post-test setelah diberikan edukasi melalui e-learning berbasis web pada pembelajaran teknologi dan informasi. Penelitian yang dilakukan oleh Zulfikar (2012), juga menunjukkan bahwa terdapat peningkatan rata-rata nilai setelah diberikannya pendidikan melalui media internet.

Berdasarkan tabel 3, hasil uji beda Paired T-Test antara skor pengetahuan pre-test dan post-test kelompok perlakuan memiliki p-value 0,050. Hal ini menunjukkan bahwa terdapat perbedaan yang signifikan antara tingkat pengetahuan ibu nifas sebelum dan sesudah diberikan edukasi gizi melalui leaflet. Hasil uji beda Paired T-Test antara skor pengetahuan pre-test dan post-test kelompok perlakuan website memiliki p-value 0,001 yang menunjukkan bahwa terdapat perbedaan yang signifikan antara tingkat pengetahuan ibu nifas sebelum dan sesudah diberikan edukasi gizi melalui website. Peningkatan nilai pengetahuan yang dimiliki responden dapat diketahui dari meningkatnya nilai median responden yaitu meningkat 35 point pada kelompok leaflet dan 30 point untuk kelompok website. Peningkatan skor pengetahuan sangat dimungkinkan karena responden saat menjawab pre-test belum menerima intervensi, sedangkan saat menjawab post-test responden sudah menerima intervensi. Pada penelitian ini, responden mengakses website melalui telepon pintar dan dijelaskan oleh ahli gizi sekitar 10-15 menit. Responden cukup antusias dalam menerima intervensi melalui telepon pintar. Responden bisa kapan dan dimana saja membaca lagi informasi yang diberikan. responden juga tertarik dengan inovasi baru media edukasi ini yang dibuat resmi dan memiliki sumber terpercaya.

Menurut penelitian yang dilakukan Fatimah dkk. (2017), menyatakan bahwa ada perbedaan yang signifikan antara

Tabel 3. Skor Pengetahuan Ibu dan Uji Beda Kelompok Leaflet dan Website

\begin{tabular}{|c|c|c|c|c|c|c|}
\hline \multirow[t]{2}{*}{ Pengetahuan } & \multirow{2}{*}{ Median Persentil (25-75) } & \multicolumn{3}{|l|}{ Nilai } & \multirow{2}{*}{$\begin{array}{c}\text { Selisih } \\
\text { Skor }\end{array}$} & \multirow[b]{2}{*}{ P Value } \\
\hline & & Min & Max & P Value & & \\
\hline \multicolumn{7}{|l|}{ Leaflet } \\
\hline Pre-test & $35(30-50)$ & 0 & 70 & \multirow{2}{*}{0,050} & \multirow{2}{*}{29,38} & \multirow{5}{*}{0,367} \\
\hline Post-Test & $70(60-70)$ & 30 & 90 & & & \\
\hline Website & & & & & & \\
\hline Pre-test & $50(30-60)$ & 20 & 80 & \multirow{2}{*}{0,001} & \multirow{2}{*}{33,13} & \\
\hline Post-Test & $80(70-90)$ & 40 & 100 & & & \\
\hline
\end{tabular}

Sumber: Data Diolah, 2020 
sebelum dan sesudah penyuluhan melalui media leaflet dengan $\mathrm{p}=0,000$. Selain itu, penelitian yang dilakukan oleh Hermawan dkk. (2017), juga menyatakan bahwa terdapat perbedaan yang signifikan setelah diberikan edukasi melalui media leaflet dengan $\mathrm{p}=0,001$. Hasil penelitian ini sejalan dengan penelitian yang dilakukan oleh Walker dkk. (2013), yang menyatakan bahwa ada peningkatan nilai pengetahuan ibu sebesar 12,5 poin setelah diberikan edukasi melalui website dengan $\mathrm{p}=$ 0,001 . Sebanyak $72 \%$ ibu merasa senang dengan adanya pembelajaran melalui media website karena ibu percaya dengan adanya pembelajaran ini dapat membantu ibu dalam proses perkembangan bayinya (Salameh dkk., 2011).

Uji beda antara kelompok leaflet dan website didapatkan dari membandingkan antara selisih rata-rata skor pre dan posttest leaflet dibandingkan rata-rata selisih skor pre dan post-test website. Rata-rata selisih skor pre dan post-test leaflet adalah 29,38 sedangkan pada website adalah 33,13. Hasil uji beda Independent Sampel T-Test pada kedua media edukasi ini adalah $\mathrm{p}=0,367$ dengan tingkat kepercayaan $95 \%$ yang berarti tidak ada perbedaan pengetahuan antara kelompok leaflet dan website setelah diberikan edukasi. Hal ini dimungkinkan terjadi karena responden pada kedua kelompok samasama antusias dalam menerima edukasi sehingga responden benar-benar membaca dengan seksama informasi yang diberikan. Tidak ada perbedaan isi informasi pada leaflet dan website. Perbedaan yang ada pada kedua media adalah gambar atau animasi yang bergerak, isi dan intervensi lain seperti penjelasan Ahli Gizi juga tidak berbeda. Jadi, tidak adanya perbedaan yang signifikan antara kelompok leaflet dan website sangat memungkinkan. Sehingga dapat disimpulkan bahwa leaflet dan website sama-sama efektif digunakan sebagai media edukasi gizi.
Hasil penelitian ini sejalan dengan penelitiaan yang dilakukan oleh Szapkiw (2013), yang menyatakan bahwa tidak ada perbedaan kemampuan kognitif pada kelompok e-booklet dengan print-book karena pada saat ini pembelajaran melalui e-booklet menjadi pilihan kedua atau penambahan media belajar setelah printbook. Pembelajaran melalui e-booklet memberikan kepuasan tersendiri bagi responden (Jeong, 2012).

Hasil penelitian ini tidak sejalan dengan penelitian yang dilakukan Setyawati dan Herlambang (2015) yang menyatakan bahwa terdapat perbedaan pengetahuan gizi pada kelompok kontrol maupun kelompok perlakuan edukasi media $e$-booklet dengan $\mathrm{p}=0,000$. Penelitian ini juga tidak sejalan dengan Putri et al. (2017), yang menyatakan bahwa terdapat perbedaan yang signifikan $(\mathrm{P}=0,000)$ ratarata perubahan skor pengetahuan sebelum dan sesudah diberikan edukasi leaflet dan website. Pengaplikasian media edukasi website dapat membantu mengurangi sampah kertas dan penekanan biaya dari pembuatan leaflet. Selain itu pengaplikasian website sebagai media edukasi sejalan dengan perkembangan teknologi yang ada.

\section{SIMPULAN}

Median skor pengetahuan ibu nifas kelompok leaflet pada saat pre-test adalah 35 kemudian pada saat post-test meningkat menjadi 70. Median skor pengetahuan ibu nifas kelompok website pada saat pre-test adalah 50 kemudian meningkat menjadi 80. Terdapat perbedaan yang signifikan $(\mathrm{P}=0,050)$ antara tingkat pengetahuan $\mathrm{ibu}$ nifas sebelum dan sesudah diberikan edukasi melalui leaflet karena hasilnya memenuhi syarat $p$-value $<0,05$. Terdapat perbedaan yang signifikan $(\mathrm{P}=0,001)$ antara tingkat pengetahuan ibu nifas sebelum dan sesudah diberikan edukasi melalui website karena hasilnya memenuhi syarat $p$-value $<0,05$. Tidak terdapat perbedaan yang signifikan 
$(\mathrm{P}=0,367)$ antara skor pengetahuan ibu pada kelompok leaflet dan website. Website dapat digunakan sebagai alternatif media edukasi pada ibu nifas Ruang Rawat Inap Peristi Ibu RSUD Sidoarjo. Membuat tampilan website yang lebih menarik agar responden lebih termotivasi untuk membaca berulang-ulang. Menambahkan video pada website agar responden lebih mendapatkan gambaran secara visual terkait materi edukasi yang diberikan.

\section{DAFTAR PUSTAKA}

Arfan, M., Wilopo, S. A., Wahyuni, B. (2010). Efektivitas Pendidikan Kesehatan Melalui E-File Multimedia Materi KRR dan Tatap Muka di Kelas terhadap Peningkatan Pengetahuan Kesehatan Reproduksi Remaja. Berita Kedokteran Masyarakat, 26(3), 107-114.

Departemen Keseahatan RI. (2006). Pedoman Umum Pemberian Makanan Pendamping Air susu Ibu (MP-ASI) Lokal. Departemen Kesehatan Republik Indonesia

Dinas Kesehatan Kabupaten Sidoarjo. (2018). Profil Kesehatan Kabupaten Sidoarjo Tahun 2018. Dinas Kesehatan Kabupaten Sidoarjo.

Fatimah, A. S. (2017). Efektifitas Penyuluhan Gizi Menggunakan PGS Card Dibandingkan Leaflet terhadap Peningkatan Pengetahuan Pedoman Gizi Seimbang pada Siswa Sekolah Dasar. Skripsi. Prodi D-IV Jurusan Gizi Poltekkes Kemenkes Yogyakarta.
Fitriana, E. I., Anzar, J., HZ. H.M. Nazir, Theodorus. (2013). Dampak Umur Pertama Pemberian Makanan Pendamping Asi Terhadap Status Gizi Bayi Umur 8-12 Bulan di Kecamatan Seberang Ulu I Palembang. Sari Pediatri, 15(4), 249-253.

Gerrits, H. (2015). Analisis Pemanfaatan Internet Untuk Meningkatkan Profesionalisme Guru. Skripsi. Fakultas Keguruan dan Ilmu Pendidikan. Universitas Pakuan.

Ginting, D., Sekarwarna, N., Sukandar, H. (2013). Pengaruh Karakteristik, Faktor Internal dan Eksternal Ibu terhadap Pemberian MP-Asi Dini pada Bayi Usia $<6$ Bulan di Wilayah Kerja Puskesmas Barusjahe Kabupaten Karo Provinsi Sumatera Utara. Tesis. Program Pascasarjana Universitas Padjadjaran.

Hermawan, H., Kurdanti, W., Tifauzah, N. (2017). Efektivitas Konseling Gizi Menggunakan Media Booklet Dibandingkan dengan Leaflet terhadap Kualitas Diet Pasien Diabetes Mellitus Tipe 2 di Puskesmas Gamping II. Skripsi. Poltekkes Kemenkes Yogyakarta.

Ifada, I., Nugroho, T. (2010). Faktorfaktor Yang Berhubungan Dengan Pengetahuan Masyarakat Mengenai Pelayanan Kesehatan Mata. Skripsi. Program pendidikan Sarjana Kedokteran Fakultas Kedokteran Universitas Diponegoro http://eprints.undip. ac.id/2 
Jeong, H. (2012). A comparison of the Influence of Electronic Books and Paper Books on Reading Comprehension, Eye Fatigue, and Perception. The Electronic Librar, 30(3), 390-408. https://doi. org/10.1108/02640471211241663.

Kementerian Kesehatan RI. (2018). Hasil Utama Riskesdas 2018. Kementerian Kesehatan Republik Indonesia.

Notoatmodjo, S. 2012. Metodelogi Penelitian Kesehatan. Jakarta: Rineka Cipta

Perdana, F., Madanijah, S., Ekayanti, I. 2017. Pengembangan Media Edukasi Gizi Berbasis Android dan Website serta Pengaruhnya terhadap Perilaku Tentang Gizi Seimbang Siswa Sekolah Dasar. Jurnal Gizi dan Pangan, 12(3), 169-178.

Rahmawati, W., Wirawan, N. N., Wilujeng, C. S., Fadhilah, E., Nugroho, F. A., Habibie, I. Y., Fahmi, I., \& Ventyaningsih, A. D. I.. (2016). Gambaran Masalah Gizi pada 1000 HPK di Kota dan Kabupaten Malang. Indonesian Journal of Human Nutrition, 3(1), 2031. http://dx.doi.org/10.21776/ ub.ijhn.2016.003.Suplemen.3

Ramadhani, M. (2012). Efektivitas Penggunaan Media Pembelajaran E-learning Berbasis Web pada Pembelajaran Teknologi Informasi dan Komunikasi terhadap Hasil Belajar Siswa Kelas X SMA Negeri 1 Kalasan. Skripsi. Prodi Pendidikan Teknik Informatika Universitas Negeri Yogyakarta.
Rohmad, N., Evi, Y. (2014). Model Pembelajaran Orang Dewasa. Surakarta: Universitas Sebelas Maret

Rohmawati, R. I. 2017. Perbedaan Skor Pengetahuan Ibu Hamil Trimester Iii Sebelum Dan Sesudah Edukasi Gizi Melalui Media Booklet Dan Website Tentang Pemberian MPASI Yang Tepat Di Kota Malang. Universitas Brawijaya

Salameh, A.A.M., dkk. 2011. Web Based Support for Pregnant Mother. Malaysia: Universitas

Sariyati, S., 2014. Faktor-Faktor yang Mempengaruhi Sikap Remaja Putri tentang Flour Albus di SMP Negeri 2 Trucuk Kabupaten Klaten Factors That Affects Adolescent Girls Attitude about Flour Albus in Trucuk 2 Junior High Schools District Klaten. Journal Ners and Midwifery Indonesia, pp.117-121.

Setiana, D., Palarto, B. dan Julianti, H.P., 2011. Pengetahuan, Sikap, Dan Praktik Mahasiswa Fakultas Kedokteran Terhadap Pencegahan Infeksi (Doctoral dissertation, Faculty of Medicine).

Sinuhaji, L.N.B., 2018. Efektifitas Penyuluan Dan Media Leaflet Terhadap Pengetahuan Dan Sikap Ibu Balita Tentang Gizi Buruk Di Dusun VII Desa Bangun Rejo Kecamatan Tanjung Morawa Utara Tahun 2018. Jurnal Ilmiah Kohesi, 2(1). 
Situmorang, J.R., 2012. Pemanfaatan internet sebagai new media dalam bidang politik, bisnis, pendidikan dan sosial budaya. Jurnal Administrasi Bisnis, 8(1).

Sugiyono. 2014. Metode Penelitian Kuantitatif, Kualitatif, dan R\&D. Bandung: CV. Alfabeta

Sunhaji. 2013. Konsep Pendidikan Orang Dewasa. Jurnal Kependidikan, 1(1), pp.1-11.

Szapkiw, A.J.R. et al., 2013. Electronic versus traditional print textbooks: A comparison study on the influence. of university students' learning. Computers \& Education, 63, pp.259-266

Walker, M.G. et al., 2013. WebBased Education for Placental Complications of Pregnancy. Journal of Obstetrics and Gynaecology Canada, 35(4), pp.334- 339.
Yunarti, Y., dan Ningsih, S. 2019. Efektifitas Penggunaan Bahan Ajar Berbasis Web terhadap Hasil Belajar Mahasiswa pada Mata Kuliah Evaluasi Proses dan Hasil Pembelajaran Universitas Baturaja. e-Tech: Jurnal Ilmiah Teknologi Pendidikan, 6(2).

Zulfikar, M.I., 2012. Pemanfaatan Media Internet Dalam Meningkatkan Efektivitas Pembelajaran Fiqih Di Kelas Xi Ips 1 Man 1 Wates Kulon Progo. Yogyakarta: UIN Sunan Kali Jaga. 